\title{
Access to Agricultural Information among Rural Farmers -A Case of Ido Local Government Area Ibadan, Oyo State, Nigeria
}

\author{
Akanni O.F. , Ojedokun C.A., Olumide- Ojo O., Kolade R.I and Tokede A.M.
}

Forestry Research Institute of Nigeria, P.M.B 5040, Jericho hills, Ibadan, Nigeria.

*Corresponding Author: barbrajo2012@gmail.com

\begin{abstract}
The study examined the level of access to agricultural technology information among rural farmers in Ido Local Government, Ibadan, Nigeria. Primary data were collected with the aid of pre-tested questionnaires and 100 respondents were selected through a two stage sampling procedure. The data was analyzed using descriptive statistics and chi-square was used to test the hypothesis.The result of the analyses indicated that (29.1\%) falls within the active age bracket of 40-60years, more than half (61.6\%) had no formal education, 70.9\% were male and 68.6\% were indigene of the study area. Majority(58.1\%) of the respondents had a little information about weather and climate, $48.8 \%$ had no information about tillage while (50\%) had a lot of information about weed control and fertilizer. Most of the farmers had little information about government related information (4.7\%), market related $(7 \%)$ and harvesting techniques( $8.1 \%)$. 50\% of the respondents in the study area strongly agreed that source of information is constraint in agricultural production while 3.5\% strongly disagreed about the source of information being a constraint. The hypothesis test revealed that there is significant relationship between marital status (< 0.05), education level $(<0.05)$ and the level of access to agricultural information in the study area. Based on the result, the study recommends that information should be disseminated to the farmers in the language that they understand and also, adult education should be encouraged in the study area to keep farmers informed towards on agricultural production practices.
\end{abstract}

Keywords-Access, Agricultural information, Climate, rural farmers, Production.

\section{INTRODUCTION}

Information is considered a vital resource alongside land, labour, capital, skills. It is facts or knowledge provided or learned as a result of research or study (Smith, 2001). Information is knowledge needed to answer some questions faced by people in their day to day activities.

The concept of information was coined by an American scientist called Robert Taylor. He stated that information is the process of asking questions. No one can categorically claim to know all the information needs especially in information relied sector like agriculture where there are new and rather complex problem facing farmers every day. It is safe to assert that the information need of farmers revolve around the resolution of problems such as pest hazard, weed control, soil fertility, farm credit, labour shortage soil erosion among others.

Obidike (2011), Petros et al., (2018) maintains that the greatest challenge facing agricultural sector is the delivery of useful information for rural communities. In most developing countries agriculture is the most important economic activity providing food, employment, foreign exchange and raw materials to industries. A significant proportion especially in the developing world has been suffering from hunger and malnutrition.

Rural farmers account for the greater part of the population of any developing country such as Nigeria. The government of a developing country have a major responsibility of ensuring that there is adequate development in their various communities and local government which could lead to effective and efficient agricultural systems that will not only supply food and animal protein but also foster the utilization of natural resources in a sustainable manner (CGIAR,1995). When the rural farmers lack access to knowledge and information that would help them achieve maximum agricultural yield; they are not only in the grope of the dark but are driven to the urban centres in search of formal 
employment, as the only option for survival (Munyua, 2000).Blait (1996) pointed out that the less expensive input for improved rural agriculture development is adequate access to knowledge and information in areas of new agricultural technologies, early warning system (drought, pest, diseases) improved seedlings, fertilizer, credit, market prices.

The general lack of awareness among farmers can be attributed to their high illiteracy (Mgbenka and Mbah, 2016), this contribute to the low level of agricultural findings. Farmers need information on production technology that involves cultivating, fertilizing, pest control, weeding and harvesting, they also need information relating to loan such as names of lenders, location and types of existing credit to reap greater profit. Grass root organs such as village heads and local.officials are used to diffuse information because of their personal touch with the small scale farmers.

The gap between theory and practice can only be reduced if correct methods of communication are implemented. These methods includes both direct and indirect communication. By directcommunication reference is made to situation where feedback can be provided instantly. Methods such as meetings and farmers' day are some examples of this mode of communication. Access to information is necessary for improving rural people livelihood (Mbagwuet al.,2018). Despite its key role in socio economic development, very few people in developing countries have access to adequate information. The information environment of the rural areas is distinct from that of the urban environment due to obvious differences. The rural areas are mostly inhabited by people with low economic potentials, illiterates, semi- illiterates, social amenities including agencies for the information dissemination. The factor of illiteracy or low level of illiteracy, school dropouts among others who have limited or no access to social amenities including agencies for the information dissemination. The factor of illiteracy or low level of illiteracy acts as a great inhibitor to information access and assimilation in rural communities in Nigeria.

Information that can help solve a problem in a development process has been a topic of extensive debate. According to Gaal (2017), the lack of adequate and relevant information as impacted negatively on any development process although academics and researchers are aware of the value of information in development, there are some concern that information is still not perceived as being as important as other resources.Meanwhile, the choice of information sources varies in individual traits, among agricultural information seekers variables such as farm size, years in farming, age, level of education, and level of income influence the choice of information sources (Riesenberg et al., 1999). If this factors can be noted it would be easier to improve access of information in rural areas. Most information services are focused in the urban areas rather than in the rural areas where help is really needed and there is a large population that lives there. Limited infrastructures, low level of illiteracy, lack of suitable information services and lack of technical competence as among the barriers to delivery of information services in rural areas in developing countries (Kamba 2009).The messages carried are not tailored to the information needs of rural populations. Even when the information is relevant, it is seldom aimed at the proper time and so does not get to the targeted audience. Another major constraint is the use of print media, leaflet and newsletters as message carries are of limited use in reaching illiterates farmers technical language used in communicating information is incomprehensible to farmers.

The objective of the study is to determine the access of information among rural farmers, identify the type of information available to them as well as the constraints encountered towards their access to agricultural information by rural farmer.

\section{METHODOLOGY}

\section{Study area}

Oyo state is one of the South Western zone of Nigeria. Oyo state is covered by Oyo-State Agricultural Development Programme (ADP) with four zones namely; Saki, Ogbomosho, Oyo and Ibadan/Ibarapa zones. Ido local government falls within the Ibadan/ Ibarapa agricultural zone.The annual rainfall ranges from 1,200-1,300 $\mathrm{mm}$. The area lies within the rainforest region of Nigeria and has two distinct seasons, the raining season from April to October with an August break and dry season from November to March. The temperatures vary from a minimum of $21^{\circ} \mathrm{C}$ in July to a maximum of $39^{\circ} \mathrm{C}$ in February. A good percentage of the populace are engaged in agriculture; producing staple crops. The state is divided into three agro ecological zones which are: the rainforest, the savannah and the derived savannah. The vegetation of the zone is evergreen forest found in the southern part. Ido local Government is located between 3'39E and 3'45E and latitude of 7'47N rainforest.

\section{Sampling procedure}

A two stage sampling technique was used for this study. The first stage involve a purposive selection of Ido local government because it is an agrarian community. The second stage involve arandom selection of eleven villages. The third 
stage involve a random selection of 10 respondents from each village except Apesan and Gedegbe where we have few farmers and just 5 respondents were selected from each village making it a total of one hundredin the study area. The selected villages are ;Apesan, Gedegbe, FenwaAdelakun,
AkindeleEgbarin, Ojuloge, Bako, AbaTesan, Alagbede, Fafunwon and Gedegbe;

\section{Method of data Analysis}

The objectives wereanalyzed using descriptive statistics such as tables, frequencies and percentages and chi-square as appropriate.

\section{RESULT AND DISCUSSION}

Table 1: Socio Economic Characteristics of respondents

\begin{tabular}{|c|c|c|}
\hline Variable & Frequency & Percentage \\
\hline \multicolumn{3}{|l|}{ Gender } \\
\hline Male & 61 & 70 \\
\hline Female & 25 & 29.1 \\
\hline Total & 86 & 100 \\
\hline \multicolumn{3}{|l|}{ Age } \\
\hline Below 20 & 15 & 17.4 \\
\hline $21-40$ & 22 & 25.6 \\
\hline $41-60$ & 25 & 29.1 \\
\hline Above 62 & 24 & 27.9 \\
\hline Total & 86 & 100 \\
\hline \multicolumn{3}{|l|}{ Education } \\
\hline No formal education & 53 & 61.6 \\
\hline \multicolumn{3}{|l|}{ Primary education } \\
\hline Secondary education & 22 & 25.6 \\
\hline \multicolumn{3}{|l|}{ Diploma } \\
\hline $\mathrm{Bsc}$ & 8 & 9.3 \\
\hline Marital status & 2 & 2.3 \\
\hline Single & 1 & 1.2 \\
\hline Married & 44 & 51.2 \\
\hline Divorced & 4 & 4.7 \\
\hline Widowed & 20 & 23.3 \\
\hline Total & 86 & 100 \\
\hline \multicolumn{3}{|l|}{ Household size } \\
\hline $1-5$ & 49 & 57 \\
\hline $5-10$ & 36 & 42 \\
\hline Above 10 & 1.0 & 1.0 \\
\hline Total & 86 & 100 \\
\hline \multicolumn{3}{|l|}{ Religion } \\
\hline Christianity & 28 & 32.6 \\
\hline Islamic & 54 & 62.8 \\
\hline Traditional & 4 & 4.7 \\
\hline Total & 86 & 100 \\
\hline
\end{tabular}

Source: Field Survey

Table 1 shows that $70.9 \%$ of the respondents are male and $20.9 \%$ are females. This implies that more males engage in farming than females. Also $17.4 \%$ of the respondents were aged below 20 years, $25.6 \%$ were aged between $21-40$ years,
$29.1 \%$ were aged between 41-60 years while $27.9 \%$ are above 62 years. This result is similar to that of Hoping (2004) who reported that farmers are of an average of 40 years. Majority ( $61.9 \%$ ) had no formal education, this is line 
with the findings of Sawio(1999) that majority of farmers had no formal education, $25.6 \%$ had primary education, $9.3 \%$ had secondary education, $2.3 \%$ had diploma while just $1.2 \%$ are degree holders.

The table also revealed that $62.8 \%$ practice Islam , 32.6\% are Christians while 4.75 were of the traditional belief . Also,
$51.2 \%$ were married, $23.3 \%$ were widowed, $20.9 \%$ are single while just $4.7 \%$ were divorced. The findings also shows that $57 \%$ of the respondents have a household size of 0-5 members, $42 \%$ had household members of between $5-10$, just $1 \%$ had above 10 members.

Table 2: Access to information among sampled respondents

\begin{tabular}{|l|l|l|l|l|l|l|l|l|}
\hline Agric information & $\begin{array}{l}\text { Very } \\
\text { much(frequency) }\end{array}$ & \% & $\begin{array}{l}\text { A } \\
\text { little }\end{array}$ & Percentage & Unsure & Percentage & $\begin{array}{l}\text { Not } \\
\text { at all }\end{array}$ & Percentage \\
\hline Weed control & 43 & 50 & 28 & 32.6 & 2 & 2.3 & 13 & 15.1 \\
\hline $\begin{array}{l}\text { Farm } \\
\text { Mechanisation }\end{array}$ & 20 & 23 & 32 & 37.2 & 2 & 2.3 & 32 & 37.2 \\
\hline Pest control and & 46 & 53.5 & 10 & 11.6 & 8 & 9.3 & 22 & 25.6 \\
\hline $\begin{array}{l}\text { Weather } \\
\text { Climate }\end{array}$ & 12 & 14.0 & 21 & 24.4 & 3 & 3.5 & 50 & 58.1 \\
\hline fertilizer & 61 & 70.9 & 25 & 29.1 & 0 & 0 & 0 & 0 \\
\hline Tillage & 10 & 11.6 & 27 & 31.4 & 7 & 8.1 & 42 & 48.8 \\
\hline Seed varieties & 16 & 18.6 & 22 & 25.6 & 5 & 5.8 & 43 & 50 \\
\hline Land preparation & 8 & 9.3 & 19 & 22.1 & 1 & 1.2 & 58 & 67.4 \\
\hline Planting method & 11 & 12.8 & 16 & 12.8 & 1 & 1.2 & 58 & 67.4 \\
\hline
\end{tabular}

Source: Field survey

Table 2 shows that $50 \%$ of the respondents had "very much" information on weed control, $32.6 \%$ had a little information on weed control, $2.3 \%$ were unsure and $15.1 \%$ did not get any information at all. $23 \%$ of the respondents had very much information about mechanization while $37.2 \%$ had a little information on farm mechanization, $2.3 \%$ were unsure and 37.2 did not get information. Also $53.5 \%$ of the respondents had very much information about pest control, $11.6 \%$ had a little information, $9.35 \%$ were unsure if they had information or not while $25.6 \%$ did not have information pertaining to pest control, this result shows that more of the respondents had information about pest control. Also $14 \%$ of the respondents in the study area had very much information about weather and climate, $24.4 \%$ had little information, $3.5 \%$ were unsure, majority $(58.1 \%)$ did not have access to any informationat all. $70 \%$ of the respondents had very much information about fertilizers, $29.1 \%$ had a little information, none of the respondents were unsure and none of the respondents

Table 3: Production Related Information Level of Access

\begin{tabular}{|l|l|l|l|l|l|l|l|l|}
\hline $\begin{array}{l}\text { Production } \\
\text { related }\end{array}$ & $\begin{array}{l}\text { Very } \\
\text { much }\end{array}$ & A little & & Unsure & Not at all & \\
\hline Storage & 23 & 26.7 & 55 & 64.0 & 3 & 3.5 & 5 & percentage \\
\hline Processing & 29 & 33.7 & 49 & 57.0 & 4 & 4.7 & 5.8 & 4.7 \\
\hline $\begin{array}{l}\text { Tools and } \\
\text { equipment }\end{array}$ & 17 & 19.8 & 54 & 62.8 & 3 & 3.5 & 12 & 14.0 \\
\hline
\end{tabular}

Source: field survey

NOTE: All figures in parenthesis are measured percentage 
Table 3 shows the level of access of respondents to production related information. $23.3 \%$ of the respondents attested that they had very much information about storage of their products $64.0 \%$ had a little; $3.5 \%$ said they were unsure and just $5.8 \%$ of them did not have access to any information at all. Also, $33.7 \%$ of the respondents in the study area had very much information about processing of their produce,
$57.0 \%$ had a little information, $4.7 \%$ were unsure and $4.7 \%$ did not have access to any information at all. However, $19.8 \%$ of the respondents had very much information about tools and equipment for processing and storing their goods, $62.8 \%$ had a little information, $3.5 \%$ were unsure and $14 \%$ of them did not have access to any information at all.

Table 4: Level of Access to Government Related Information

\begin{tabular}{|l|l|l|l|l|l|l|l|l|}
\hline $\begin{array}{l}\text { Government } \\
\text { Related }\end{array}$ & $\begin{array}{l}\text { Very } \\
\text { much }\end{array}$ & & A little & & Unsure & & Not at all & \\
\hline & Frequency & Percentage & frequency & Percentage & Frequency & Percentage & Frequency & Percentage \\
\hline $\begin{array}{l}\text { Government } \\
\text { Policy }\end{array}$ & 4 & 4.7 & 36 & 41.9 & 6 & 7.0 & 40 & 46.5 \\
\hline Infrastructure & 10 & 11.6 & 37 & 43.0 & 6 & 7.0 & 33 & 38.4 \\
\hline Programme & 20 & 23.3 & 35 & 40.7 & 6 & 7.0 & 33 & 38.4 \\
\hline
\end{tabular}

Source : field survey

NOTE: All figures in parenthesis are measured in percentage.

From table 4 above, $4.7 \%$ of the respondents attested that they had very much information about government policy, $41.9 \%$ had a little, a while $3.0 \%$ were unsure and $46.5 \%$ did notb have access to any information at all. Also $11.6 \%$ of the respondents had very much information about government infrastructures, $43 \%$ had a little information, $7.05 \%$ were unsure and $38.4 \%$ of them did not have access to any information at all. $23.3 \%$ of the respondents in the study area had very much information, $40.7 \%$ had a little information, $7.0 \%$ were unsure and $29.1 \%$ did not have access to any information at all.

Table 5: Level of access to market related information among sample respondents

\begin{tabular}{|c|c|c|c|c|c|c|c|c|}
\hline $\begin{array}{c}\text { Market } \\
\text { related }\end{array}$ & $\begin{array}{c}\text { Very } \\
\text { much }\end{array}$ & A little & & unsure & & Not at all & \\
\hline frequency & Percentage & frequency & Percentage & frequency & percentage & Frequency & Percentage \\
\hline Market price & 6 & 7.0 & 50 & 58.1 & 1 & 12 & 29 & 33.7 \\
\hline $\begin{array}{c}\text { A variable } \\
\text { market }\end{array}$ & 6 & 7.0 & 59 & 68.6 & 3 & 3.5 & 18 & 20.9 \\
\hline
\end{tabular}

Source: field survey

NOTE: All figure in parenthesis are in percentage

Table 5 shows that $7 \%$ of the respondents had very much information about market price at which to sell their goods, $58.1 \%$ had a little, $1.2 \%$ were unsure and $33.7 \%$ did not have access to any information which shows that most of the respondents did not have access to any information about market price. Also $8.1 \%$ of the respondents got very much information about available market price, $60.5 \%$ had a little information about available market, $3.5 \%$ were unsure and $27.9 \%$ did not have access at any information at all.

Table 6: Level of access to harvesting related information among sampled respondents

\begin{tabular}{|c|c|c|c|c|c|c|c|c|}
\hline $\begin{array}{c}\text { Harvesting } \\
\text { related }\end{array}$ & Very much & A little & & unsure & & Not at all & \\
\hline & Frequency & Percentage & Frequency & percentage & frequency & Percentage & frequency & Percentage \\
\hline Method & 7 & 8.1 & 52 & 60.5 & 3 & 3.5 & 24 & 27.9 \\
\hline Tools & 4 & 4.7 & 52 & 60.5 & 2 & 2.3 & 28 & 32.6 \\
\hline
\end{tabular}

NOTE: All figures in parenthesis are in percentage 
Table 6 reveals that $8.1 \%$ of the farmers had very much information about harvesting methods, $60.5 \%$ had little information $3.5 \%$ were unsure and $27.9 \%$ did not have access to any information at all. Also $4.7 \%$ of the respondents had very much information, $60.5 \%$ had a little, $3.5 \%$ were unsure and $32.6 \%$ did not have access to any information at all.

Table 7: Constraints to access of information among respondents

\begin{tabular}{|l|l|l|l|l|l|l|l|l|}
\hline Constraints & $\begin{array}{l}\text { Strongly } \\
\text { agree }\end{array}$ & & Indifferent & & disagree & & $\begin{array}{l}\text { Strongly } \\
\text { disagree }\end{array}$ & \\
\hline & Frequency & Percentage & Frequency & Percentage & frequency & percentage & frequency & Percentage \\
\hline Source & 43 & 50.0 & 4 & 4.7 & 36 & 41.9 & 3 & 3.5 \\
\hline $\begin{array}{l}\text { Cost of getting } \\
\text { information }\end{array}$ & 59 & 68.6 & 4 & 4.7 & 18 & 20.9 & 5 & 5.8 \\
\hline Availability of & 56 & 65.6 & 7 & 8.1 & 12 & 14.0 & 11 & 12.8 \\
\hline $\begin{array}{l}\text { Cost } \\
\text { utilization }\end{array}$ & 79.1 & 13 & 15.1 & 3 & 3.5 & 2 & 2.3 \\
\hline $\begin{array}{l}\text { Government } \\
\text { policy }\end{array}$ & 74 & 86.0 & 9 & 10.5 & 1 & 1.2 & 2 & 2.3 \\
\hline Others & 73 & 84.9 & 10 & 11.6 & 1 & 1.2 & 2 & 2.3 \\
\hline
\end{tabular}

Source: Field Survey.

Table 7 shows the constraints to access and usage of agriculture information. $50 \%$ of the respondents in the study area strongly agreed that source of information is constraint, $4.7 \%$ were indifferent, and $41.9 \%$ disagreed and $3.5 \%$ strongly disagreed about the source of information being a constraint. Also $68.6 \%$ of the respondents agreed that the cost of getting information is a constraint to access and usage of agricultural information, $4.7 \%$ were indifferent, $20.95 \%$ disagreed and just $5.8 \%$ of the strongly disagreed about it. $65.1 \%$ of the respondents agreed that availability of information is a constraint, $8.1 \%$ were indifferent, 14 disagreed and 12.8 strongly disagreed, $79.1 \%$ of the respondents strongly agreed that cost of utilization is a constraint, $15.1 \%$ were indifferent, $3.5 \%$ disagreed and $2.3 \%$ strongly disagreed. $86 \%$ agreed that government policy is a constraint, $10.5 \%$ were indifferent, $1.2 \%$ disagreed and $2.3 \%$ strongly disagreed. Other constraints mentioned by the respondents were, access to loan, collateral problems, language barrier etc. $84.6 \%$ of the respondents agreed that the other constraints were greater, $11.6 \%$ were indifferent, $1.2 \%$ disagreed and $2.0 \%$ strongly disagreed.

\section{Hypothesis of the study}

Chi-square was used to analyze the hypothesis, since it is measured at a nominal level. H01: There is no significant relationship between the socio economic characteristics of the respondents and access to agricultural information.

\begin{tabular}{|l|l|l|l|l|}
\hline VARIABLES & $\mathbf{X 2}$ & DF & P-VALUE & REMARK \\
\hline Age & 2.088 & 3 & 0.554 & Non significant \\
\hline Gender & 2.229 & 1 & 0.135 & Non significant \\
\hline Marital status & 11.307 & 3 & 0.010 & Significant \\
\hline Household size & 1,835 & 2 & 0.400 & Non significant \\
\hline Religion & 3.103 & 2 & 0.212 & Non significant \\
\hline education & 9.920 & 4 & 0.042 & Significant \\
\hline
\end{tabular}

The result from the table above revealed that there is a relationship between the socio economical characteristics and access to agricultural information. From the table the martial status has a significant relationship with the access to agricultural information (0.010) in the study area and also the level of education also shows a positive significant relationship (0.042), and thus the h01 hypothesis which states that there is no significant relationship between socio economical characteristics and access to agricultural information is rejected and a new hypothesis which states 
that there is a significant relationship between socio economical characteristics and access to agricultural information is accepted.

\section{CONCLUSION}

The study examined the level of access to agricultural information of rural farmers in Ido local government, Nigeria. From the results of the study most of the farmers in the study area had no formal education (61.6), (70.9) the highest percentage of the respondents were male and (29.1) were within the active age bracket of 41-60 year, also 68.6\% of the respondent were indigenes of the study area. Most of the respondents in the study area had a little information about weather and climate, machines, tillage seed varieties, land preparation and planting information while a large percentage had a lot of information about weed and fertilizer due to the actions of profit oriented organizatiosn who give the farmers this information so as to be able to sell their goods. Most of the farmers had little information about production of goods, government related information, market related and harvesting techniques. From the result, it can be observed that the respondents in the study area have an inadequate level of information. However there is a significant relationship between educational level, marital status and the access to agricultural information which means that the household size and marital status had a positive effect on the level of access to agricultural information in the study area.

\section{RECOMMENDATION}

The following are the recommendation made based on the findings of the study.

* Agricultural information should be extended to remote villages.

* Agricultural information should be explained in the simple and understandable language to the rural farmers

* Loans with little or no collateral should be given to farmers.

* Farmers input band machinery should be sold to farmers at subsidized rate

* Installment payment for inputs and machinery should be accepted.

* Adult education should be encouraged

\section{REFERENCES}

[1] Balit, S., Calvelo Rios,M. \& Masias, L. (1996). Communication for development for Latin America: a regional experience. FAO, Rome, Italy
[2] CGIAR (1995). Renewal of the CGIAR: sustainable agriculture for food security in developing countries. Ministerial-level Meeting, Luceme, Switzerland, CGIAR, Washington, D.C. USA. Pp. 133.

[3] Gaal H.O. (2017). Lack of Infrastructure: The Impact on Economic Development as a case of Benadir region and Hir-shabelle, Somalia. Developing Country Studies.Vol.7, No.1.

[4] Mbagwu C.F., Benson V., and Onuoha O. (2018). Challenges of Meeting Information Needs of Rural Farmers through Internet-Based Services: Experiences from Developing Countries in Africa. Retrieved from http://library.ifla.org/2195/1/166-mbagwu-en.pdf on August 27th, 2019.

[5] Mgbenka R. N. and Mbah E.N. (2016). A Review of Smallholder Farming in Nigeria: Need for Transformation. International Journal of Agricultural Extension and Rural Development Studies.Vol.3, No.2, pp.43 - 54.

[6] Munyua, H. (2000). Apllication of information communication technologies in the agricultural sector in Africa: a gender perspective. In: Rathgeber, E, \&Adera, E.O.(Eds.) Gender and information Revolution in Africa IDRC/ECA. Pp. 85-123

[7] Obidike N. A. (2011). Rural Farmers' Problems Accessing Agricultural Information: A Case Study of Nsukka Local Government Area of Enugu State, Nigeria. LibraryPhilosophy and Practice - Electronic Journal, ISSN 1522 - 0222.

[8] Petros .T., Nachimuthu .K., Atinikut .H., Mohammed (2018)Agricultural Extension: Challenges of Extension service for rural poor and youth in Amhara Region, North Western Ethiopia. The Case of North Gondar Zone. International Journal of Scientific Research and Management. Vol 6, No 2, Page No.: AH-2018-05-14.

[9] Riesenberg, Luo .E. and Christopher. O. Gor. "Farmers' Preferences for Methods of Receiving Information: New or Innovative Farming Practices." American Association for Agricultural Education 30.3 (1999).

[10] Smith, T. Concise Oxford English Dictionary (COD10).Oxford: Oxford University Press, 2001.Print 